2) SFピルテスタからもとめたビルライフ曲線を上 式にあては， $k_{2}$ ，HWTをもとめ $k_{2}$ が大きくHWTが 小さいほど抗ピル性があると判定する。

\section{文献}

1）例えば，特公昭 45-11480，46-15147など

2）例えば，特公昭 36-6190，41-17040，41-20416, 45-7692, USP 3332832,3108356 ,
BP 1003697 など

3）幾機学会編；基礎織維工学〔1〕,p.146(1976)

4) Grunewald ; Chemiefasem,12,835(1962)

5) DuPont ; Neth 300965 (1965)

6) 特公昭 41-20416(1966)

7) R. H. Brand ; Text. Res.J. 37, 467(1967)

8）特公昭 47-2776(1972)

9）奉公昭 44-4643(1969)

10) 辻本石雄, 元治信雄; 緎学誌, 20,768(1964)

(昭和 50 年 4 月 25 日受理)

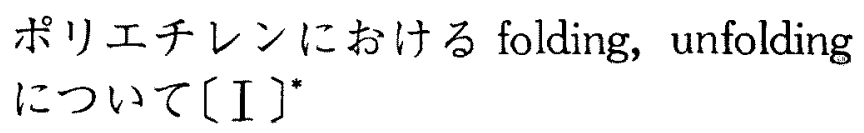

ュニチカ拣式会社中央研究所田川高司・田絧稔英

鹿息勝

\title{
CHAIN FOLDING AND UNFOLDING IN POLYETHYLENE (I)
}

\author{
By Takashi Tagawa, Toshihide Tabuchi and Masaru Kashima \\ (Research \& Development Center, UNITIKA Ltd. \\ 23 Kozakura, Uji, Kyoto 611 , Japan)
}

\begin{abstract}
The present paper gives a method to evaluate fold-content, $C_{f}$ in polyethylene (PE) from IR measurement $\left(1200-1400 \mathrm{~cm}^{-1}\right)$. Solution-grown crystals of n-paraffin and PE were adopted as standard specimen containing no fold $\left(C_{f}=0\right)$ and $100 \%$ fold $\left(C_{f}=1.0\right)$, respectively and mixtures of these substances were used for the determination of constants, $k$ and $K$, in Koenig's equation. The values of $C_{f}$ obtained from two pair of absorption bands (from each sample) showed good agreement for various $\mathrm{PE}$ samples.
\end{abstract}

(Received April 25, 1975)

\section{1. 緒 言}

ポリエチレン、ナイロン6，66，PETなど，多くの結 晶性高分子が，固体中で折りたたみ鎖からなるラィラ構 造をとることはよく知られている。また，末延伸構造体 中のラメラの折りたたみ分子鎖が延伸によって解きほぐ され，㵶維搆造にうつること，熱姏理によって一たん形 成された瀻維構造からラィラ構造が再生されることも周 知のことがらである。これらの現象は, 分子鎖の unfoldingやrefoldingで巧く説明されるが，このような 機構が考えられるに至った根拠の多くは、これまで単結
晶や固体表面について、答形、熱処理にともなうモルホ 口ジーの変化を追った多くの電子顕砫鏡観祭の結果にあ ると思われる。このように、電子顕制鏡はこの方面の研 究に有力な情報をもたらすが，電子影溦鏡といえども， 微細なラ゙ィラの一敕一枚を捉えることは。条件が整わぬ かぎりなかなか容易でないし、まして、ラメラ中の個々の 分子鎖や，変形中のラメラの動き，folding, unfolding しつつある分子鎖の挙動を直接観察することは，現在の ところ，不可能と云ってもよいであろう。

高分子固体中の foldの状悲をX線による測定から調 ベようとした試みも一，二みられるが1,2)，foldに関す る直接的な情報をえることにはかなりの困難があるよう に思われる。この点, 郝攻収スベクトルはポリマー鎖

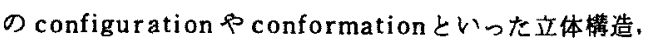


水絜結合，結晶性，分子配向などの environmental effectsに敏感であるから、ラメラ表面の分子鎖の fold 状焦が变化したり，一定の conformationをもつ regu-

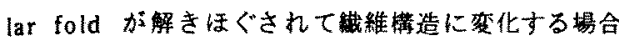

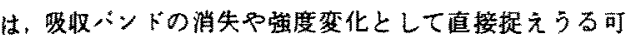
能性がある。著者らはこの考えに凅って、ポリエチレン の延伸や熱始理による folding - unfolding を赤外吸彼 スベクトルからより正確に激定することを試みた。本報 でその定量方法の詳細につけて述べる。

\section{2. 赤外スペクトルかららの fold の定星法}

ボリマー鎖の folding や unfoldingの様子を赤外吸収 スベクトルから検知するには、それぞれのスペクトルに fold箐造に䅦属できる吸収バンドの存在が必要である。 Koenig ら 高結晶性状態のスペクトル，末た熱观理や化学処理をほ どこしたときのスベクトル変化から，各吸収ヘンドを crystalline, noncrystalline, crystallizable拉 び fold ジトに分類する方法で foldハンドをみつけ出 し.種々のオツゴマ一や類似物質のスベクトルとの比較 によって fold ベンドとしての㷌属起確かめている。彼 等の得た結果を表】にまとめた。このうち，例光ばナへ ロン6のd㤠结晶では $1,210 \mathrm{~cm}^{-1}<1,288 \mathrm{~cm}^{-1}$ Ogauche nitrogen methyleneダルーブによる吸收が、またナイ ロン66結晶では $1,329 \mathrm{~cm}^{-1} の \mathrm{~N}$-vicinal methylene クループの吸収が，それぞれ foldハントに㷌属されて いる。これらはナイロン䥊のアミド基周边の confor mationが， fold中のものだけ特殊な形態をとるため現 われるもので，メルトや非晶状態で情消失するバンドで ある゙

ポリエチレンではナ.イロソの場合と少し異なる。いま， ラィラ状結晶の表面が regular foldで篈われて找り。 結昆内部は理想的な敉序を保っているものとする。ボリ ×チンの regular foldが(110) foldで,かり

$\cdots(\mathrm{T})_{c r y} \cdots \mathrm{T} \cdot \mathrm{GTGGTGGG} \cdot \mathrm{T} \cdots(\mathrm{T})_{\text {cry }} \cdots$ で示される一定の conformationをとるならば，結晶内 部はトランス (T)满造代かりで， fold 部分はトランス

Table 1 Fold bands in various polymers

\begin{tabular}{llc}
\hline Polymer & $\begin{array}{l}\text { Bands related to } \\
\text { chain folding }\end{array}$ & References \\
\hline PE & 1350,1304 & $(7)$ \\
Nylon 6 & $1288,1233,1210$ & $(4)$ \\
Nylon 66 & 1329,1224 & $(5)(6)$ \\
PET & 988 & $(3)$ \\
Amylose & 1295 & $(8)$ \\
Amylopectine & 1295 & $(9)$ \\
\hline
\end{tabular}

（T）とゴーシュ（G）が一定の順序で連なったものから なる。ボりマーには結晶部分ばかりでなく、非晶部分も あり、そこにはT、G，G*がランダムに配列した分子鎖 があるから，鎖の各セグントにおけるこれらのrotational is omer ものとして赤外スべタトル上で識別することはできない。 従って、ポリェテレンにはfold 単独に慢属させ得る吸 取ヘンド存在しない。しかし，分子鎖が一定の conformation tとって，規测正しく亚んだ fold 面上に存 在するGTGやGGセグメトの吸収保数は，全く無秩序 な配向状熊にある分子鑟中のGTGやGGと算なるとの考 えから. Koenig ら” は foldと非昆の両方の寄与によっ て生ずる $1,304,1,350 \mathrm{~cm}^{-1}$ 両バンドの強度を次のよう に考えた。

$$
\begin{aligned}
& D_{\mathrm{L}, \mathrm{s} 0 \mathrm{O}}^{\prime}=k_{7} C_{d}+k_{8} C_{f} \\
& D_{\mathrm{L}, 904}^{\prime}=k_{8} C_{d}+k_{10} C_{f}
\end{aligned}
$$

ここで.

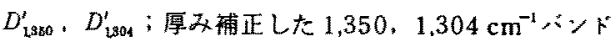
の吸收光度

$k_{7} ; 1,350 \mathrm{~cm}^{-1}$ ペンドの disorder 部分による吸光倸 数

$k_{8} ; 1,350 \mathrm{~cm}^{-1}$ ペンドの fold 部分による吸光係数

$k_{\mathrm{g}} ; 1,304 \mathrm{~cm}^{-1}$ ×゙ンドの disorder 部分による吸老係 数

$k_{10}: 1.304 \mathrm{~cm}^{-1}$ ハンンドの fold 部分による吸光䋀数

$C_{d}$; 試料中の disorder 部分の分率

$C_{f}$; 試料中の fold 部分の分率

式 (1)，(2)加 $5 C_{d}$ を消去すると次式を得る。

$$
D^{\prime}{ }^{2504}-k D_{1,500}^{\prime}=K C_{f}
$$

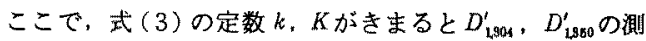
定值から末知試料中の fold 含有率 $C_{f}$ を求めることがで きる。

いま，foldを全く含市い試料があると，武（3）の 右辺は 0 となり， $k$ を求めることができる。

$$
k=D_{1,304}^{t} / D_{\mathrm{L}, 800}^{t} \quad \text { (no folds) }
$$

Koenig らは高E結晶化試料に刘して式(4)を適用し， $k=0.46 \pm 0.01$ を得た。しかしKをきるることはできず， $C_{f}$ 㯈を単独に求めることはできなかった。この場合， 式（4）に代入する $D_{1,304}^{\prime} ， D_{\text {L,s50 }}^{\prime}$ は高殴結晶化陚料中に存 在する disorder 部のみの寄与によることになるが，と もに小さい值であるから，測定上の困難は避けられない。

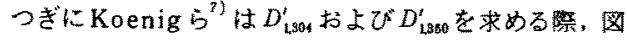

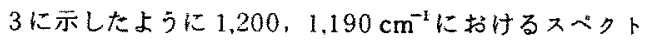
ル上の 2 点索結んで $1.170 \mathrm{~cm}^{-1}$ まで延長した点をぺース ラインとする peak hight 法によっている。得られた結 果の如何は别として，fold 颉の決定に最も重要な゙ン 
ド強度を求める上で,この方法は多少根拠に欠けるとこ ろがあるように思われる。

また, 式 (3)からC $C_{f}$ を求める際は, 式 (1)，（2）で示 されるように $D_{1,860}^{\prime} ， D_{1,304}^{\prime}$ が disorder 部分と fold 部分 の 2 成分から成立つことを前提とする。従って, この式 におけるdisorderやfoldは，どの試料においてもそ れぞれ同じ吸光係数 $k_{7}, k_{9}$ および $k_{8}, k_{10}$ をもち得る状 態のものである必要がある。一定の conformation をと る fold 部分はよいとしても，さまざまな結晶状態や分 子配向状態にともなわれた各試料の disorder 部分に, 果してこのような仮定を適用し得るか否かには議論の余 地があろう。

上述のKoenig 式における理論上の問題点は一まずお いて, 著者らは一たん式 (3) 確認し,この式における定 数 $k 、 K$ を決定し, 各パンドの吸光度をできるだけ正確 に測定することによって $C_{f}$ を求め,これから式 (3)の 妥当性を再検討することを企てた。この目的を達するた めに，著者らは一定層厚をもつポリエチレン単結晶 $\left(C_{f}=\right.$ $1.0)$ とパラフィン単結晶 $\left(C_{f}=0\right)$ を基準試料とし, 他を normalizeする方法で任意の試料中の fold 量を示すこ ととした。また吸光度の測定には波形解析による面積強 度法を採用した。

Snyder ${ }^{10)}$ によれば，ポリエチレンの $1,400 〜 1,200$ $\mathrm{cm}^{-1}$ に出現するパンドは表 2 のように帰属されている。 Koenig が用いた $1,350,1,304 \mathrm{~cm}^{-1}$ ハンンドはそれぞれ ×チレン鎖のGG, GTG* conformationに由来する。

Table 2 Band assignment for IR spectrum of PE

\begin{tabular}{lcl}
\hline Bands & Intensity & \multicolumn{1}{c}{ Assignment } \\
\hline $1378 \mathrm{~cm}^{-1}$ & $\mathrm{~m}$ & methyl bending \\
1368 & $\mathrm{~m}$ & methylene bending -GTG*- \\
1353 & $\mathrm{~m}$ & methylene bending -GG- \\
1344 & wsh & methylene bending -TG- \\
1308 & $\mathrm{~m}$ & methylene bending -GTG*- \\
1270 & $\mathrm{wsh}$ & methylene bending -GTmG*- \\
\hline
\end{tabular}

表から， $1,368 \mathrm{~cm}^{-1}$ の強いバンドも $\mathrm{GTG}^{*} に$ 㷌属されて いるので, 式 (2) と同様, $D_{1368}^{\prime}$ も disorder 部分と fold 部分から成るものとして処理す机ば，.1,368 $\mathrm{cm}^{-1}$ と 1,350 $\mathrm{cm}^{-1}$ の両ハンドを用いた場合にも $C_{f}$ 値を算出し得る筈 である。以下にはこれら2 組のパンドから得られた結果 を比較して述べる。

\section{3. 実: 験}

\section{1 基準試料}

fold 量を表わす基準として，つぎの 2 種類のサンプ ルを使用した。

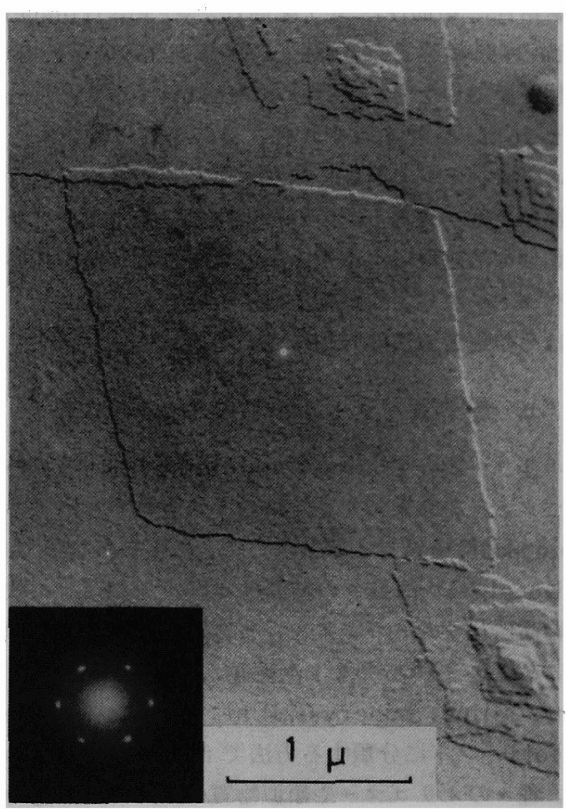

Fig. 1 Electron micrograph and electron diffraction pattern of standard PE crystals $\left(C_{f}=1.0\right)$

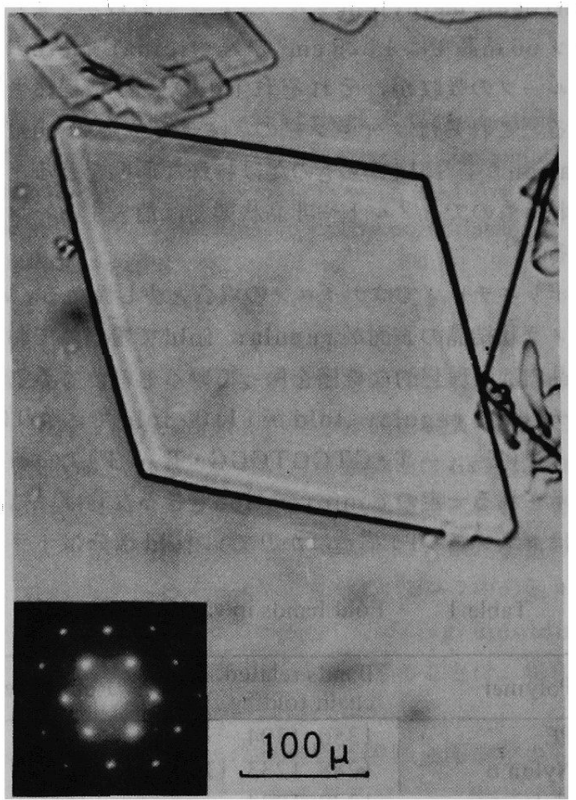

Fig. 2 Optical micrograph and electron diffraction pattern of standard n-paraffin crystals $\left(C_{f}=0\right)$ 
a）基準ポリエチレン単結晶：一般に稀薄溶液から 析出させられたボリエチレン単結晶の表面は regular tight foldで覆わ扎てると考えられている。線状ポ リエチレン（Sholex 6009）を0.1\%のキンレン溶夜か ら $80^{\circ} \mathrm{C} 24 \mathrm{hrs}$ 等温結晶化させ，高温洰別して得た単結 晶試料の fold 含有量を 1.0 と定めた。この試料の䉓子䫏 做鏡写真と電子線回折図を図 2 に示した。この単結晶の 配向マットの小角散乱長周期は113 13 であった。いま, この基準試料のラメラの表裹が完全に regular foldて 覆われているとすると，陚料中の fold 輻は約 $5 \times 10^{20}$ 個 $/ \mathrm{cm}^{\mathrm{g}}$ と計算される。

b）基準 $n$ ーバラフィン单結晶：鎖長の短い $n$ ーパラ フィンは分子鎖が伸び切った状態で結晶化することが期 待される。兄-hexatriacontane $\left(\mathrm{C}_{38} \mathrm{H}_{74}\right)$ は種々の結 晶形で析出するらしく，P.W. Teare ${ }^{11)}$ は，高沸点の石 油から結晶化させた試料について結晶解析を行なって，

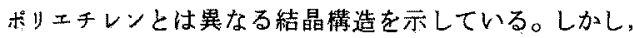
著者らは㣫々の溶媒から析出させた単結晶の無配向マッ トにつけて調べた結果， $n$ 一hexatriacontaneはアセト ソの0.1\%溶液加 $46^{\circ} \mathrm{C}$ で結晶化させた場合、表 3 に示 すよ5に上記の基集ポリエチレン単結晶と極めて近い面 間隔をもつことを見出した。この試料についての詳しい 結晶構造解析は行なっていないが，この単結晶の配向マ

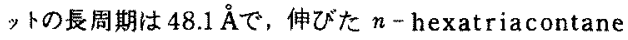
分子長の計算值 $45.7 \AA$ より僅かに大きいこと，図 2 に示 す光学䫒諴鏡写真および電子線回折図加ら，各分子は伸 び切って結晶板面にほぼ垂直に立っており，ポリェチレ ンと類似の unit cell 在もつ結晶で,そのラメラの表面 には foldを合まないものとみて、この試料の fold 含有 量を0と定めた。

c) 单結晶混合試料：式（3）の常数 $k ， K$ を求めるた めに，種 々の fold 含有量の試料が必要になる。これら の試料は a)拈よ゙゙）の各単結晶を調整した際，その結 晶化浴の溶媒をそれぞれ水に固換しておきこれら2種 の単結晶のサスペンジョンを任意の割合で混合し，無配 向マットに成型することによって調整した。マット中の

Table 3 Interplanar spacing of standard PE and n-paraffin crystals

\begin{tabular}{cccc}
\hline hkl & $\begin{array}{c}\text { Experimental }(\AA) \\
\mathrm{C}_{88} \mathrm{H}_{74}\end{array}$ & PE & $\begin{array}{c}\text { Calculated }(\AA) \\
\text { PE }\left(B u n n^{12)}\right)\end{array}$ \\
\hline 110 & 4.115 & 4.115 & 4.102 \\
200 & 3.711 & 3.708 & 3.696 \\
210 & 2.963 & 2.966 & 2.956 \\
020 & 2.473 & 2.473 & 2.467 \\
120 & 2.337 & 2.337 & 2.340 \\
011 & 2.276 & 2.259 & 2.254 \\
310 & 2.212 & 2.210 & 2.203 \\
\hline
\end{tabular}

ボリエチレンとパラフィンの混合比は，それぞれの試料 の $890 \mathrm{~cm}^{-1}$ 扎よ゙ $910 \mathrm{~cm}^{-1}$ の赤外吸取ヘントから正確 に定めることができた。

\section{2 赤外スペクトルの測定}

赤外スベクトルの測定には，譈小試料での測定を考慮 して，日本分光社製 DS - 201 型赤外分光光度計を無偏 光で使用した。スべクトルは波形解析に適するよう，波 数，吸光度等分目盛で記録した。波数軸は 4 倍に拡大 (11.8 cm/100 $\left.\mathrm{cm}^{-1}\right) \mathrm{L}$, じ西5ぶんな感度と迤いscan speedを用いた。碳小陚料にはとくに設計したbeam condenserあるいは赤外顕徽装固を併用した。

\section{3 波形解析}

赤外スペクトルの波形解析は Du Pont 社製 310 型波 形解析装置によって行なった。この装后はナナログ型計 算機で，あらかじめ指定して記憶させた䛜数曲線のいく つかを，位直，高さ，幅をかえてブラウン管上につくり 出し，それらの合成曲線の像を解析しようとする亦外ス ぺクトルの像と half mirror上で重ね合わせる方式の ものである。ブラシン管上では10本までの曲線の合成が できる。

波形解析は以下に述べる方法で行なった。

a) 各バンドのベースラインは， $D_{1,904}^{\prime}, D_{2,960}^{\prime} の$ 組合わ せを用いる場合， $1,400 \mathrm{~cm}^{-1}$ と $1,200 \mathrm{~cm}^{-1}$ 附近の2 点に 接する直楾を引き， $D_{2,968}^{\prime} ， D_{\mathrm{L}, 550}^{\prime}$ の組合わせの場合には $1,400 \mathrm{~cm}^{-1}$ と $1,330 \mathrm{~cm}^{-1}$ 附近の2点に接する直線を引 いて, ペースラインとした。

b) 各バンドの函数形は，この波数域の各ビークに最 もよく合うガウス曲線とした。

c） $1,400 \sim 1,200 \mathrm{~cm}^{-1}$ の領域内で、種々のポりエチ レン試料について各バンドの波数変化を調べたところ， いずれも数 $\mathrm{cm}^{-1}$ 以内であるので，各ビークの位置は Snyder ${ }^{10)}$ の带属表の值， $1,378 ， 1,368 ， 1,353,1,344$, $1.303 ， 1,207 \mathrm{~cm}^{-1}$ に固定した。

d）各ピークの波数位置を固定しても、ブロードなピ 一クの重なったスベクトルでは、ピーク高さ拉よび輻を かえると幾通りもの解に波形分離できることがある。こ の不都合を避けるために，われわれは標準ポリエチレン 単結晶試料について数多くの解析を行ない，その中加ら 各ハン・ド間の强度関係やピーク幅が最も自然に波形解析 されたと思われる1枚のキャートを標準解析曲線に選ん だ。以後の波形解析を行なら㻮は，必ず一たん装置をこ の摽準解析曲線に合わせて各ビークの位固, 幅, 高さを 記憶させた後，チャートをかえて未知陚料のスぺクトル に合わせるために，まず，各ビークの高さのみを加减し てできるだけ一致する合成曲線をつくり，ビうしても合 わない場合にのみ、わずかにビーク湢をがる方法によ 


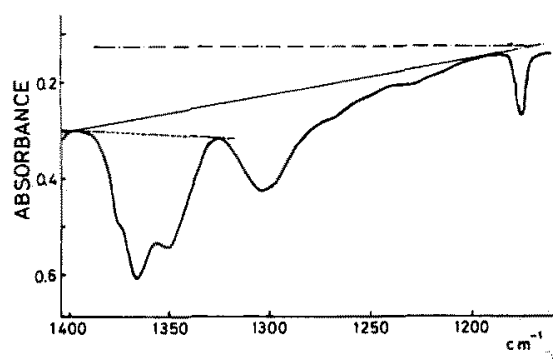

Fig. 3 Base lines to evaluate the intensities of IR bands -.- Koenig's method for 1304 and $1350 \mathrm{~cm}^{-1}$

Method I for 1304 and $1350 \mathrm{~cm}^{-1}$ Method II for 1368 and $1350 \mathrm{~cm}^{-1}$

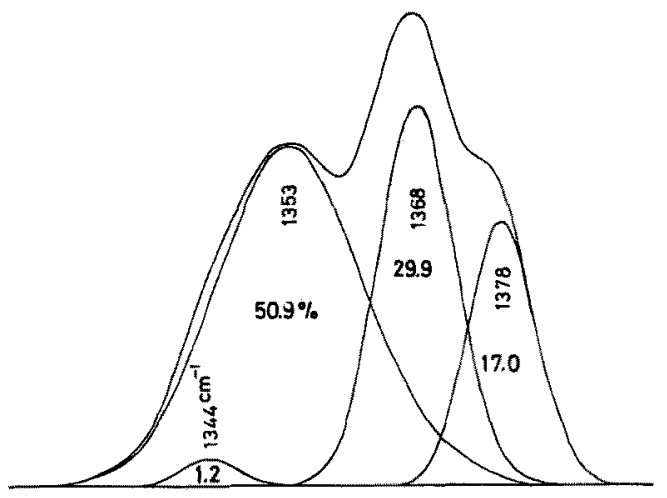

Fig. 4 Standard resolving curve for the spectrum of standard PE single crystal sample

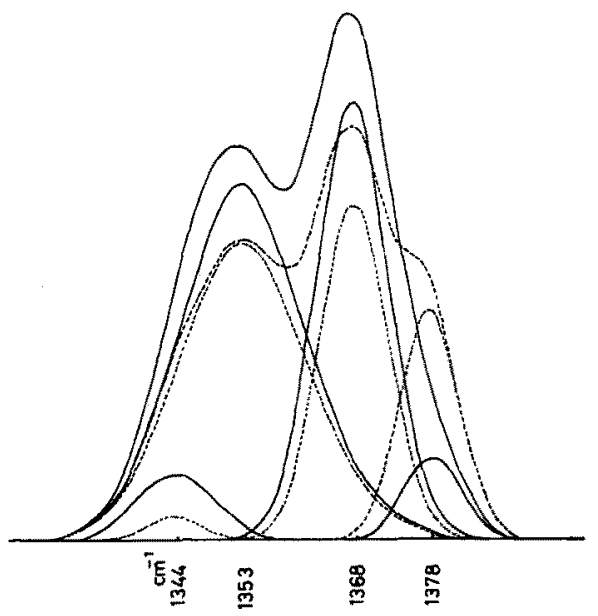

Fig. 5 An example for curve resolving of unknown sample

Unknown sample

-... Standard resolving curve shown in Fig. 4
って波形解析した。国 4 に $1,400 \sim 1,330 \mathrm{~cm}^{-1}$ を 4 七一

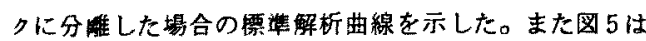
この標淮解析曲線から出発した未知試料の解析結果の1 例である。

e）各ピークの面䅡は装值についた面摃計から䛃み上 った。

\section{4. 結果および考察}

Koenig ${ }^{7)}$ は $1,304 \mathrm{~cm}^{-1}$ と $1.350 \mathrm{~cm}^{-1}$ の雨くントを 用いて，fold 量に関係する梿を求奴。前述のように， これらはィチレン鎖のGTG*，GG conformationに相 当し，同じ㷌属のバンドの組合わせは $1,368 \mathrm{~cm}^{-1}$ と 1,350 $\mathrm{cm}^{-1}$ でもつくり得る。明光度を peak height法で求め たKoenigのやり方では，両ボンドの波数位陧が大きく 離れている前者の組合わせの方がやり易いかも知れない が，波形解析による面鈢法を用いた著者らの方法では， 各ハントは接近していても構わず，むしろ全パンドに共 通なべースラインを容易に引き得る利点がある。ここで は上記の 2 組の組合わせが䎧討された。

赤外スペクトルの吸収ヘンドの画数形は，一般に Lorentz型に近いものが多いとされている。ポリこ子 レンの波形解析を行なら昜合にむ，他の波数域に現われ る鋭いハントに対してはLorentz曲線で巧く僻でさ るが,ここで取报った $1,400 〜 1,200 \mathrm{~cm}^{-1}$ の各パンドは Gauss 曲線がよく合W，Larentz曲線では分離できな い。これは，これらの各ハンドが五立した 1 個のセグ ントの運動によるだけでなく，堆辺分子からの envi一 ronmental effectsを旗くうけていることの影んとみ ることができよう。

Wま， $1,400 \sim 1,200 \mathrm{~cm}^{-1}$ の領域を图 3 の実線で示す ベースラインによって 1,378，1,368，1,353，1,344，

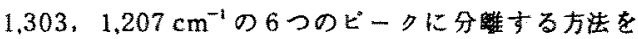
“波形解析法－I”とし，1,400 1,330 $\mathrm{cm}^{-1}$ 域を图 30 破線で示すべースラインによって 1,378，1，368，1,353， $1,344 \mathrm{~cm}^{-1}$ の 4 つヒビークに分睢する方法を“波形解析 法一II"とする。

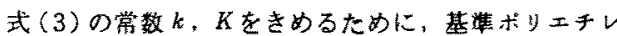
ン単結晶と基準ハラフィン単結晶を種んの割台で混合し てマっトをつくり，その赤外スペクトルを記録した。 $1,400 \sim 1,200 \mathrm{~cm}^{-1}$ 城の1例を図6に揭げた。 fold の定 舅に用いる各ボントは强度が弱く，ボリエチレン含量が 10 \%以下ではどータが不明瞭となり，定量しにくくなる。 マット中のポリメチレンとバラフィンの分率は890，910 $\mathrm{cm}^{-1}$ バンドの面䅡強度比から，ま大試料の厚み補正は阔

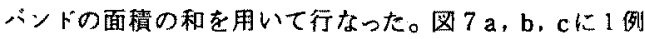
として波形解析法一片のり方て $1.400 \sim 1.330 \mathrm{~cm}^{-1}$ t 4 


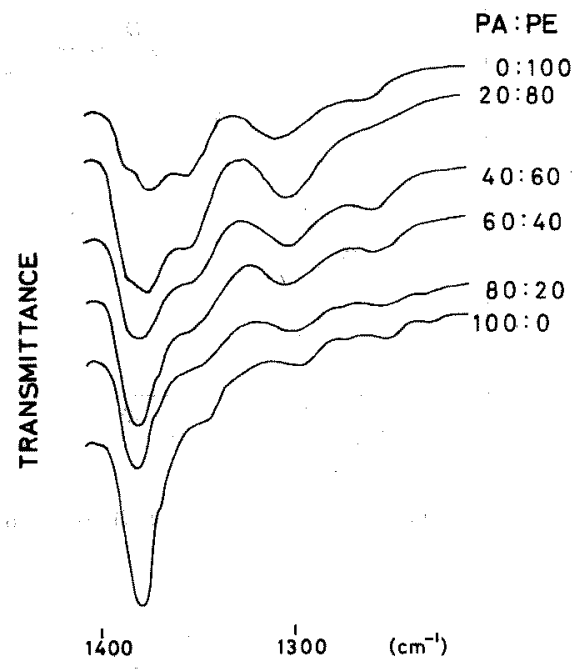

Fig. 6 Changes in spectra of PE by mixing paraffin

つのピークに分離し，愿み補正を行なった各バンドの吸光 度と，基准繥晶の混合比の関係を示した。ィチル基の bendingに㷌属される $1,378 \mathrm{~cm}^{-1}$ パンドは，バラフィン の含有率の增加にともなって直線的に增大し，メチレンの GTG* ${ }^{*}, \mathrm{GG}$ conformation $\sigma$ bending motionに㷌属 される $1,368,1,350 \mathrm{~cm}^{-1}$ バンドは，パラフィンの增加 とともに減少することから，波形解析がほぼ妥当に行な われていることがかかる。

式（3）の両辺をC

$$
\frac{D_{1,304 \text { or } 1388}^{\prime}}{C_{f}}-k \frac{D_{1,569}^{\prime}}{C_{f}}=K
$$

を導き，上記各試料について実測した各パンドの明光度 值 $D^{\prime}$ と実測泥合比からら求めた各 $C_{f}$ 値を式 (5)に代入し， 最小 2 莱法を用いて $k ， K$ を算出した。ちなみに図 $7 に$

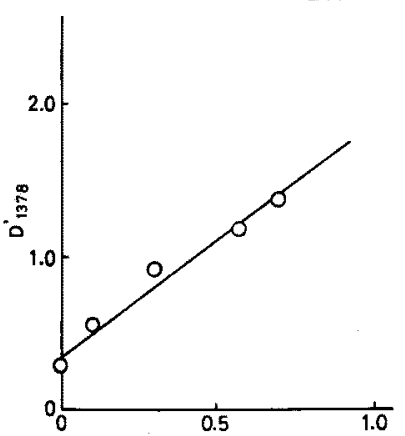

PA WEIGHT FRACTION

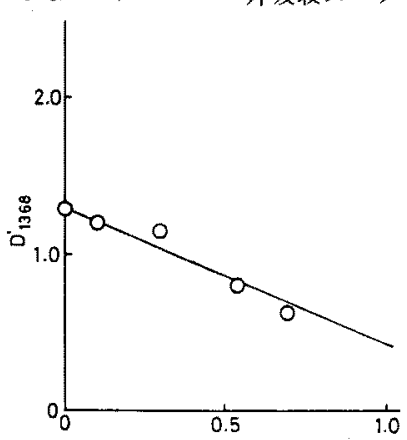

PA WEIGHT FRACTION
示した各吸光度値を用いて式 (5)をplotすると図 8 が 得られる。

上述の方法によってKoenigの与えた式 (3)の常数 $k$, Kが定まる。Koenigが用いた $1,350 \mathrm{~cm}^{-1}$ と1,304 $\mathrm{cm}^{-1}$ バントの組合わせについて，波形解析法－Iで行なった 結果， $k=0.49 \pm 0.01 ， K=0.14$ を得た。これから

$$
D_{\mathrm{L}, 304}^{\prime}-0.49 D_{\mathrm{L} 8 \mathrm{B0}}^{\prime}=0.14 C_{f}
$$

を得る。また $1,368 \mathrm{~cm}^{-1}$ と $1,350 \mathrm{~cm}^{-1}$ の両ハンントに対す る波形解析法一IIの適用によって，同様に

$$
D_{\mathrm{L}, 988}^{\prime}-0.82 D_{1,950}^{\prime}=-0.55 C_{f}
$$

が得られた。

式 (6)，(7)をチェックする意味で, 上述の基隼単結 晶混合試料の一連のデータについて, 実测の漉合比率か ら求めた $C_{f}$ 値之，その試料の昅光度から式 (6)あるい は（7）を用いて求めた $C_{f}$ 值の関係をplot した。結果は， 因 9, 図 10に示すように，両式とも㕕いポリェチレン 含有量域で実測によるものとよい一致を示すことを確か め。

以上の結果から，式 (6)末たは（7)を用いれば，吸光 度を測定することによって，未知陚料中の fold 含有量 $C_{f}$ を求めることができる。いま，式 (6)，(7)が同一 試料に対してどの程度異なる結果を与えるかを知るため に、二、三の試料について測定した結果を因 11 に示し た。図はポりエチレンフイルムを延伸した場合，延伸倍 率の增加にともなって fold 量の減少する様子を示して 怙り，その挙動は $1,350,1,304 \mathrm{~cm}^{-1}$ バンドよる式 (6)でも，1,368, $1,350 \mathrm{~cm}^{-1}$ バンドの式(7)でもほぼ 等しいことが明らかとなった。

\section{5. 結論}

ポリエチレン固体中の fold 量を測定するために，赤 外吸収スベクトルを利用する方法について检討した。基

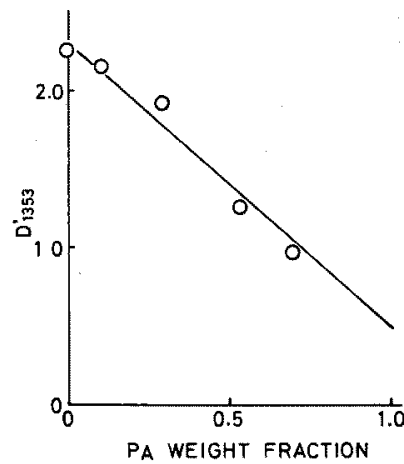

Fig. $7 \mathrm{a}$ Changes in band intensities Fig. $7 \mathrm{~b}$ Changes in band intensities $\left(1378 \mathrm{~cm}^{-1}\right)$ by mixing paraffin (PA) with PE $\left(1368 \mathrm{~cm}^{-1}\right)$ by mixing paraffin (PA) with PE
Fig. $7 \mathrm{c}$ Changes in band intensities $\left(1353 \mathrm{~cm}^{-1}\right)$ by mixing paraffin (PA) with PE 


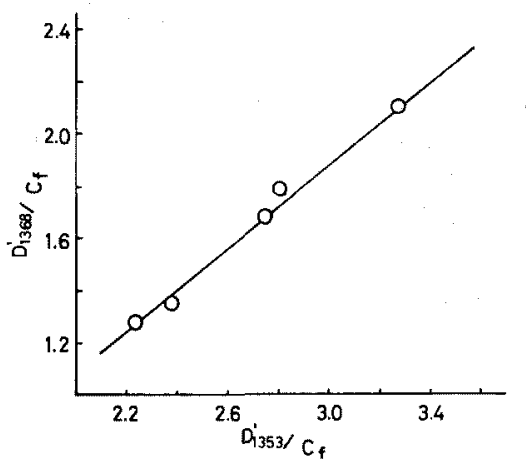

Fig. 8 Linear relationship obtained from Eq. 5 by plotting $D_{1368}^{\prime}$ and $D_{1353}^{\prime}$

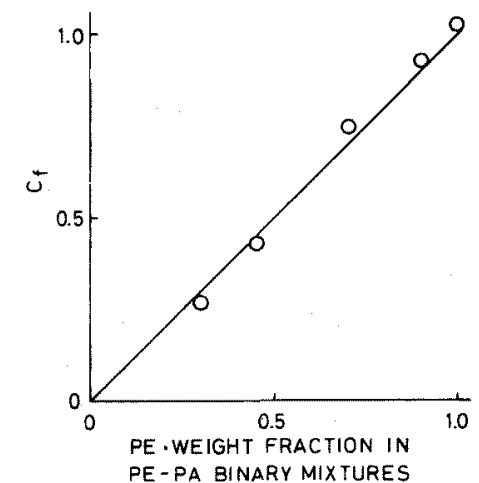

Fig. 10 Graphical representation of validity of Eq. 7.

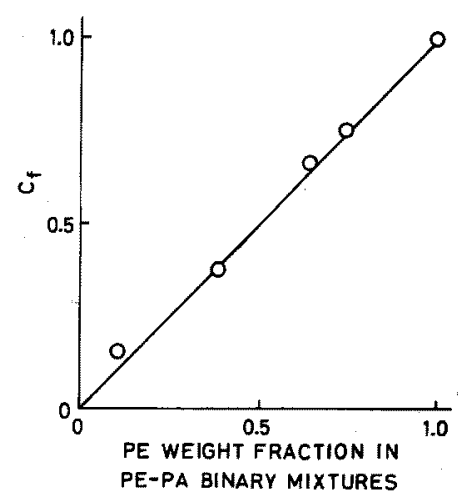

Fig. 9 Graphical representation of validity of Eq. 6

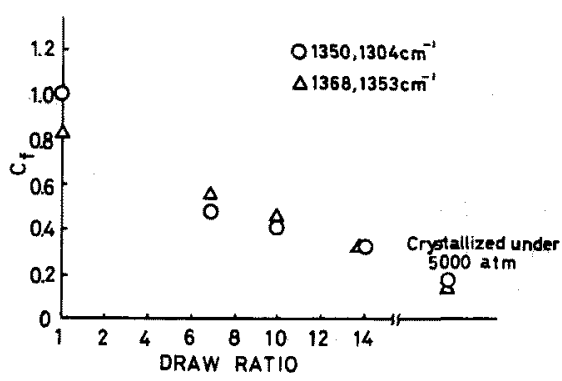

Fig. 11 Comparison of experimental results by using Eq. 6 with that by Eq. 7 for various PE specimens.

\section{文 献}

1) E.D.T. Atkins, A. Keller and D.M. Sadler; $J$. Polymer Sci., A-2, 10, 863 (1972)

2) P. Dreyfuss and A. Keller; J. Macromol. Sci-Phys ., B4, $811(1970)$

3) J.L. Koenig and M.J. Hannon; ibid, B1, 119 (1967)

4) P.D. Frayer, J.L. Koenig and J.B. Lando; ibid, B6, $129(1972)$

5) J.L. Koenig and M.C. Agboatwalla; ibid, B2, 391 (1968)

6) P.D. Frayer, J.L. Koenig and J.B. Lando; ibid, B3, 329 (1969)

7) J.L. Koenig and D.E. Witenhafer; Makromol Chem., 99, 193 (1966)

8) J.L. Koenig and P.D. Vasko; J. Macromol SciPhys, B4, 347 (1970)

9) P.D. Vasko and J.L. Koenig; ibid, B6, 117 (1972)

10) R.G. Snyder; J. Chem. Phys, 47, 1316 (1967)

11) P.W. Teare; Acta Cryst., 12, 294 (1959)

12) C.W. Bunn; Trans. Faraday Soc., 35, 482 (1939) 